\title{
Nano-economics, spinoffs, and the wealth of regions
}

\author{
Steven Klepper
}

Accepted: 1 July 2011 / Published online: 19 August 2011

(C) Research Institute of Industrial Economics 2011. This article is published with open access at Springerlink.com

\begin{abstract}
The historical evolution of four prominent industry clusters is compared: automobiles in Detroit, Michigan, tires in Akron, Ohio, semiconductors in Silicon Valley, California, and cotton garments in Dhaka, Bangladesh. Detailed data are collected concerning the intellectual and geographic origins of entrants into the clusters and other regions to probe the mechanisms underlying geographic clustering. The main mechanism at work in the four clusters involves employees leaving established firms to found their own firms or shape new entrants in their industry. Questions and policy implications related to the spinoff mechanism and the mobility of employees are discussed.
\end{abstract}

Keywords Spinoffs - Clusters - Agglomeration economies

JEL Classifications $\mathrm{R} 11 \cdot \mathrm{R} 12 \cdot \mathrm{L} 26 \cdot \mathrm{L} 63$

Steven Klepper is the 2011 Winner of the Global Award for Entrepreneurship Research. This essay is the Prize Lecture given upon receipt of the Award on 18 June 2011 in Stockholm, Sweden. For more information about the Prize and previous Winners see www.e-award.org.

S. Klepper $(\square)$

Department of Social \& Decision Sciences, Carnegie Mellon University, Pittsburgh, PA, USA

e-mail: sk3f@andrew.cmu.edu

\section{Introduction}

Why do some industries cluster in one or a few geographic regions that do not possess any natural advantages for producers in the industry?

Much has been written about this question in recent years. Alfred Marshall's (1920) influence is unmistakable. Marshall conjectured that firms cluster geographically because (initially) it is beneficial. The benefits come in three forms. First, when firms cluster then labor clusters. The clustering of labor makes it easier for firms and workers to match their idiosyncratic characteristics, making both more productive. It may also reduce the incidence of unemployment. Second, clustering facilitates learning from other firms, via localized technological spillovers, enabling all firms in clusters to be more productive. Third, when firms in an industry cluster it gives an incentive for their suppliers to cluster there also, thereby lowering transactions costs and making both the firms and their suppliers more productive.

All of these benefits, which are called agglomeration economies, are considered externalities. When firms enter, they confer benefits on other firms located nearby that they generally do not take into account in their entry and location decision. Therefore, clustering will occur to a lesser extent that is socially optimal without public intervention. Therein lies the interest in clustering-it can justify proactive public policies.

To what extent is the evidence consistent with Marshall's conjectures? This is difficult to assess 
because the mechanisms underlying each type of agglomeration economy are hard to spot. Take, for example, technological spillovers. Many years ago Krugman (1991), who popularized Marshall's ideas in modern times, wrote that technological spillovers leave no paper trail. Subsequent researchers claimed that citations to patents could be used to track technological spillovers and endeavored to show that patent citations are more localized than would be expected based on the location of producers in an industry (Jaffe et al. 1993). This mechanism alone would not support technological spillovers promoting clustering, which requires a further chain of reasoning. But whether the evidence even supports this first step in the argument has been hotly disputed (Jaffe et al. 2005; Thompson and Fox-Kean 2005a, b). The evidence supporting the other two prongs in the Marshallian argument is similarly limited.

The case for clustering is based on more indirect evidence. Some studies examine the extent to which the productivity of firms is related to the concentration of activity nearby in their industry and other industries. Others look at how wages, employment growth, and entry are related to the same factors. Yet another strategy is to see whether industries in which Marshall's agglomeration economies might be expected to be more important are more concentrated geographically. A related strategy is to see whether firms in two industries that trade with each other, use similar types of workers, or are related through innovation are more likely to locate close to each other. By and large, the evidence from such studies supports the importance of all three of Marshall's mechanisms (Audretsch and Feldman 2004; Rosenthal and Strange 2004; Ellison et al. 2010; Puga 2010).

The main purpose of this paper is to synthesize evidence from a different strategy that I have been using in recent years to probe for the mechanisms underlying geographic concentration. The evolution of industries that ended up heavily geographically clustered is dissected to see whether they evolved in common ways, and if so, what this tells us about the determinants of industry agglomeration.

Four extreme clusters are considered. The first two, automobiles and tires in the USA, emanate from my earlier work on industry shakeouts. Both industries experienced extreme shakeouts, which is why I chose to study their evolution in great depth.
I developed a theory of shakeouts that predicted that earlier entrants would be more likely to be long-term survivors in these and other shakeout industries. By tracking every firm that entered the automobile and tire industries in the USA, including when they entered and exited, I could test this prediction (Klepper 2002).

Along the way data were also collected on the base location of every entrant in the two industries. Indeed, where firms were located was key to using annual lists of firms to corroborate which ones were continuing producers, which ones exited in any given year, and which ones were new producers. Automobiles and tires are two of the most famously clustered industries in U.S. history. Everyone knows about the clustering of the automobile industry around Detroit, which continues to this day. The tire industry was clustered to pretty much the same extent around Akron, Ohio, a small city in northeastern Ohio. Unlike autos, the Akron cluster petered out beginning in the late 1930s, but in its heyday it was comparable to Detroit in being the center of the tire industry.

Originally I did not have any particular insights into why either industry became so heavily clustered geographically. On the surface, the experience of both industries seemed entirely consistent with the Marshallian view. Then I stumbled across a simple observation about the automobile industry and its first great firm, Olds Motor Works, which led me in a different direction (Klepper 2005, 2007) that will be elaborated. It also led me to expand my inquiry to two other extreme clusters. One is the clustering of the U.S. semiconductor industry in Silicon Valley (Klepper 2009, 2010), which is one of the great industrial wonders of the modern world. Every region wants to be the next Silicon Valley, and every country would like to grow the next Silicon Valley. The other extreme cluster that I chose to study is the cotton garment industry in Bangladesh (Mostafa and Klepper 2010). In some ways this is an even more extraordinary cluster than the semiconductor industry in Silicon Valley. It helped catalyze sustained economic growth in a country handicapped by numerous challenges.

These four industries and how they evolved is my empirical palette. Collecting the evidence required to pursue the insight inspired by Olds Motor Works proved to be challenging. It helps define what one of my colleagues calls my style of analysis. There is 
macroeconomics, microeconomics, and nano-economics, which involves digging below the microeconomic level to understand the evolution of industries. In the context of the evolution of industry clusters, nano-economics required me to trace the intellectual and geographic heritage of the firms that entered the studied industries, particularly the new firms that entered these industries. This required identifying and tracking the founders of the new firms, a task which required a different strategy for each industry. Ultimately, what has emerged is a novel theory of clustering based on the ideas of organizational reproduction and heredity. The theory raises numerous questions and yields novel public policies.

The effort to collect the requisite evidence was arduous, and collaborators were essential in my work. Two were partners in my geographical explorations. Guido Buenstorf and I collaborated in the investigation of why the U.S. tire industry became so clustered around Akron (Buenstorf and Klepper 2009, 2010), which involved tracing the intellectual and geographic heritage of all the firms that historically entered the tire industry in the state of Ohio. Romel Mostafa and I collaborated on the investigation of the cotton garment industry in Bangladesh (Mostafa and Klepper 2010). He conducted the lengthy fieldwork in Bangladesh that was essential to our investigation, and that only occurred after over a full year of assembling and coding archival data on the industry from his perch in Pittsburgh.

This paper is organized as follows. In Section 2, the histories of the four clusters are recounted. In Section 3, the ideas inspired by Olds Motor Works and how they formed the basis for the investigation of the evolution of the four clusters are presented. Section 4 describes the effort that was devoted to collecting evidence to test the ideas. Section 5 describes the tests. Section 6 discusses the results, raising numerous questions and also discussing distinctive policy implications of the view about clusters that emerges from the four case studies.

\section{Four famous clusters}

One of the earliest great industry clusters to emerge in the USA without an obvious natural advantage was the concentration of automobile producers around Detroit, Michigan. Figure 1 plots the collective

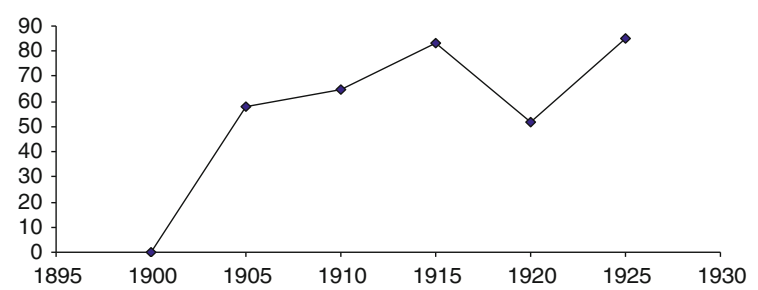

Fig. 1 Percentage of U.S. automobile output accounted for by firms based in the Detroit area, 1900-1925. Source: Bailey (1971), Federal Trade Commission (1939)

market share of automobile producers located in the Detroit area every 5 years from 1900 to 1925 based on data on the output of leading makes of automobiles reported in Bailey (1971) and the total output of automobiles reported by the Federal Trade Commission (1939). Firms moved about and branched within roughly a 100-mile region in Michigan from Detroit. Accordingly, the Detroit region is defined to include all locations in Michigan within 100 miles of Detroit, including prominent automobile cities such as Flint and Lansing.

The automobile industry is generally dated as beginning in the USA in 1895. Curiously, among the first 69 producers in the industry through 1900 listed in Smith (1968), none entered in the Detroit area. The first firm in the Detroit area deemed by Smith (1968) to be a producer (i.e., a firm that manufactured a car and sold to the general public) was Olds Motor Works, which was a successful engine producer that developed the first really popular automobile, the Curved Dash Runabout. After Olds, another 109 firms entered in the Detroit area through 1924, after which entry into the industry was negligible.

Figure 1 indicates that automobile firms based in the Detroit area captured a rising share of the industry's output after Olds' entry. By 1910, firms in the Detroit area accounted for $65 \%$ of the output of the industry, which rose further to over $80 \%$ in 1925 and subsequently remained high. Not surprisingly given the size of the automobile industry, Wayne County, which is home to Detroit, expanded by leaps and bounds, increasing from a population of 300,000 in 1900 to 1.9 million in 1930 .

The most successful of the early Detroit area firms was Ford Motor Co. It entered in Detroit in 1903 and captured over $50 \%$ of the total market by 1915 . In the 1920 s, Ford was displaced as the industry leader by General Motors, which was a merger of a number of 
firms built around Buick Motor Co., a Detroit area producer that entered in 1903. The last of the big three producers, Chrysler, emerged in Detroit in 1924 through the efforts of Walter Chrysler, the ex-head of the Buick division of General Motors, to reorganize two successful early producers that had fallen on hard times. However, Detroit was a lot more than just Ford, General Motors, and Chrysler, and a number of other leading firms were also located there.

The pneumatic tire industry was pretty much a creation of the automobile industry. Pneumatic tires had been used on bicycles, but scaling them up to much heavier automobiles presented a novel challenge that effectively created a new industry. The first producer of a pneumatic automobile tire in 1896 was B.F. Goodrich, which had been a successful producer of bicycle tires and other rubber products. It was based in Akron, Ohio, a small city in Northeastern Ohio near Cleveland. Four other early leaders of the industry also emerged in Akron, namely, Diamond Rubber, Kelly-Springfield, Goodyear Tire \& Rubber, and Firestone Tire \& Rubber. According to the annual listings of pneumatic tire producers in Thomas' Register of American Manufacturers, through 1930 over 500 firms entered the tire industry. Ohio had the most entrants of any state with 126, and 102 of these entrants were located within 100 miles of Akron.

Figure 2 plots the periodic share of U.S. tire production accounted for by establishments in Ohio (mainly northeastern Ohio) from 1899 to 1935 based on Census data, initially for the combined tire and rubber industry and then for the tire industry alone beginning in 1919 when it was broken out separately. The share of tire production in Ohio increased steadily through 1935 , peaking at $67 \%$. The bulk of this output was accounted for by Goodrich, which acquired Diamond in 1912, Goodyear, and Firestone.

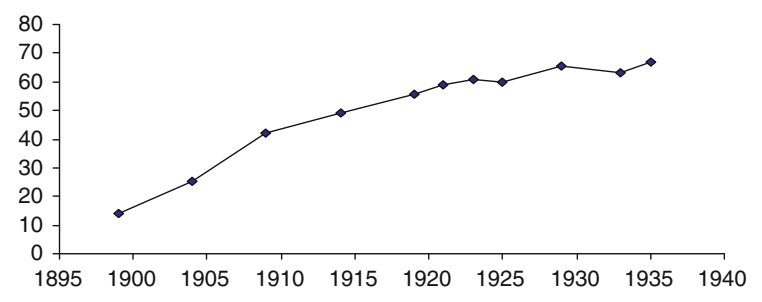

Fig. 2 Percentage of rubber and tire production accounted by establishments in Ohio, 1899-1935. Source: U.S. Census of Manufactures, various volumes



Fig. 3 Percentage of sales of U.S. semiconductor firms accounted for by firms based in Silicon Valley, 1957-1990. Source: Tilton (1971), Sales data compiled by Integrated Circuit Engineering

However, the next cadre of firms in Ohio also comprised sizable producers, accounting for around one-third of the Ohio plant capacity as of 1921 (Buenstorf and Klepper 2009). Similar to Wayne County, the population of Summit County, the home of Akron, increased greatly, rising five-fold from 70,000 in 1900 to 350,000 in 1930 .

The semiconductor industry was launched by the transistor, which was invented in 1947 at Bell Labs, AT\&T's research arm located in New Jersey. Semiconductor firms were initially concentrated in New York, Boston, and Los Angeles. Similar to the automobile industry and Detroit, at first no semiconductor company located in Silicon Valley. The first great semiconductor firm in Silicon Valley was Fairchild Semiconductor, which entered in 1957. According to the Silicon Valley genealogy, which reports the founders of all semiconductor firms in Silicon Valley through 1986, ${ }^{1}$ over 120 firms entered in Silicon Valley after Fairchild Semiconductor.

Figure 3 plots the periodic share of the sales of U.S. semiconductor firms accounted for by firms based in Silicon Valley from the start of the industry through 1990. It is based on the market shares of the leading firms reported periodically in Tilton (1971) through 1966, and then it is reported in 5-year intervals from 1975 to 1990 based on firm sales data compiled by the private consulting firm Integrated Circuit Engineering (ICE). The graph reflects the steady rise in the market share of the Silicon Valley semiconductor firms after the entry of Fairchild Semiconductor, which reached a peak of approximately $50 \%$ in 1985. Silicon Valley is based in Santa Clara county, whose population surged from

\footnotetext{
${ }^{1}$ It was compiled by Semiconductor Equipment and Materials International of Mountain View, CA.
} 
300,000 in 1950 to 1.3 million in 1980 as the semiconductor industry increasingly concentrated there. A number of entrants after Fairchild Semiconductor contributed to Silicon Valley's dominance of the semiconductor industry, including National, Intel, and AMD.

Thus, in the three U.S. clusters, over 100 firms entered in a 30-year period, and the firms in the clusters grew to account for $50 \%$ or more of the total sales of U.S. firms in their industry. The regions of each cluster also grew greatly and became inextricably linked to their industry, evidenced no better than by Silicon Valley, which derived its name from the silicon used in semiconductors.

The fourth cluster that is considered is somewhat different. For one, it was not in the USA but in a poor country that had relatively recently gained its independence, Bangladesh. Furthermore, it involved an old, low-tech industry, cotton garments, whereas autos, tires, and semiconductors were new and highly innovative industries. But like the other three clusters, the growth of the cotton garment industry in Bangladesh, in particular in its capital city of Dhaka, was extraordinary.

Before 1978, there was no cotton garment industry to speak of in Bangladesh. Indeed, Bangladesh had little industry and was beset by corruption and low literacy. A South Korean firm, Daewoo, initiated a partnership with a Bangladeshi who agreed to start a cotton garment firm, Desh Garments, in the port city of Chittagong. The South Korean firm was coming up against international export limits and sought out a partner to enhance its earnings. Desh Garments sent 126 workers to South Korea to be trained by Daewoo for 6 months in every aspect of its business, including the assembly line production of shirts and other cotton garments. The workers returned to Bangladesh, and Desh Garments began production under Daewoo's supervision. Daewoo handled all other aspects of the business, including marketing and sourcing of inputs.

After 2 years a coup occurred in South Korea, and the head of Daewoo was forced to leave the country, which led to Desh Garments breaking its agreement with Daewoo. On its own it continued to be successful. A flood of entrants followed Desh Garments into the cotton garment industry, mainly in Dhaka. According to records compiled by the Bangladesh Garment Manufacturers and Exporters
Association (BGMEA), a total of 664 firms entered the industry by 1988 . Figure 4 reflects the enormous growth of the industry over time and the concomitant growth of the Bangladeshi economy. Since 1980, Bangladesh has averaged per capita gross domestic product (GDP) growth of 5\% per year and is on the verge of giving up its status as a less-developed country. Its exports have grown comparably, driven by the growth of the cotton garment industry, which accounts for over $75 \%$ of its exports. Today, there are over 4,500 cotton garment factories employing three million workers, with $80 \%$ or so of the factories located in Dhaka.

All four of the clusters were located in regions without any particular natural advantages for their industry. They represent some of the most extreme examples of such industry clustering in modern times. As such, it might be thought that any lessons that could be gleaned from the four clusters would be illuminating about the forces governing the geographic concentration of industries.

\section{A theory of organizational reproduction and heredity}

My thinking about clustering was profoundly influenced by a brief passage in an old book about the automobile industry by Doolittle (1916), The Romance of the Automobile Industry. Doolittle (1916, pp. 44-45) described Ransom Olds, who headed Olds Motor Works when it entered the automobile industry in 1901, as the "Schoolmaster of Motordom." He claimed that Olds "probably trained more men of prime importance to the industry to-day than any other pioneer" and went on to feature three of his employees that were especially important founders of Detroit area automobile companies.

This suggested a mechanism that might help explain the clustering of the automobile industry in the Detroit area. Incumbent firms are natural training grounds for the next generation of entrepreneurs in an industry. Suppose that the better the performance of a firm, the more valuable the lessons that its employees can learn about how to organize a firm in the same industry, which is called a spinoff. The profitability of a potential spinoff would depend on the lessons learned by its employee-founder and the employee's ability to organize his own firm. If the distribution of 
Fig. 4 Gross domestic product per capita and exports of Bangladesh, 1959-2000. Source: International Monetary Fund for GDP data, Bangladesh Export Promotion Bureau for the export data

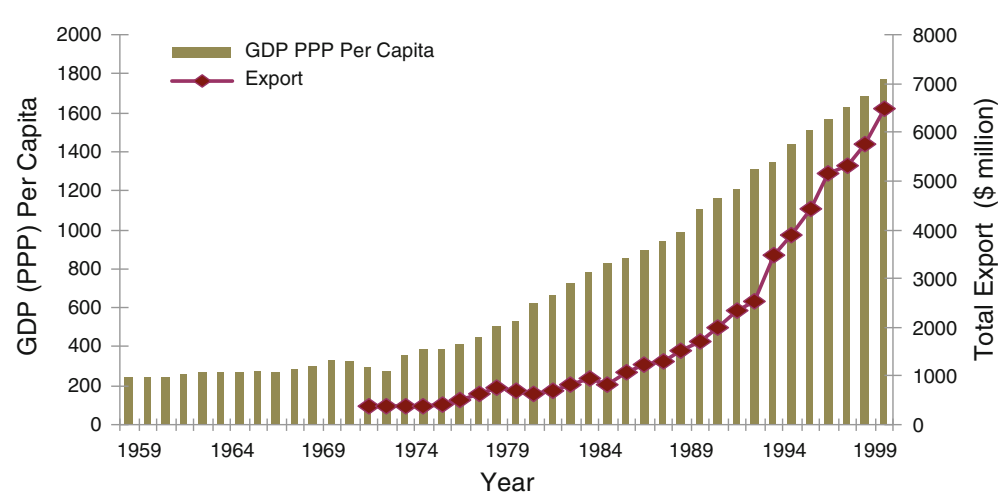

employees in terms of their ability to organize a spinoff was the same at all incumbent firms, then employees in better firms would be more likely to found (profitable) spinoffs and to have better (i.e., more profitable) spinoffs. ${ }^{2}$ If employees locate their spinoffs close to their prior location, this could lead to a buildup of successful spinoff firms around successful early entrants, giving rise to industry clustering.

This idea seemed especially promising as a way of explaining the clustering of the automobile industry in the Detroit area because Olds Motor Works was not only successful itself, but it also played an important role in the success of three other early entrants in the Detroit area, namely, Cadillac, Ford, and Buick. Although Olds had been a successful engine producer before entering the automobile industry, it subcontracted production of all its parts and focused on assembling automobiles. Its two main suppliers of engines and transmissions were two local machine shops, Leland and Faulconer and the Dodge Brothers. Capitalizing on their experience working for Olds, these two firms were instrumental in the success of Cadillac and Ford, which entered in Detroit in 1902 and 1903, respectively. Another one of Olds' local subcontractors, the Briscoe Brothers, financed Buick, which entered into automobile production in 1903 in Detroit. Although Buick was not initially successful, it became one of the leading producers in the industry after being acquired by William Durant, a successful wagon producer in Flint, Michigan who moved the company there. In 1908 he used Buick to organize General Motors.

Thus, the Detroit area was home to four of the most successful early entrants into the industry. This could hardly have been predicted. Detroit was a

\footnotetext{
2 This prediction would be reinforced if better firms also had more able employees (Klepper and Thompson 2010).
}

sizable city, but not especially well positioned to become the capital of the U.S. automobile industry given its distance from the main population centers in the northeastern part of the USA. However, if spinoffs are key to industry clusters, then the chance concentration of four of the early leaders in the Detroit area could well have set the stage for the clustering of the automobile industry there.

Many questions are raised by this explanation for clustering. What exactly is learned from working inside a successful company that is so useful in starting a spinoff? Presumably something tacit that is hard to learn without experiencing it first hand. Why do employees leave incumbent firms to start spinoffs and how do they manage to succeed in competition with a successful "parent"? Why would employees locate their spinoffs close to their parent firm rather than seek out less populated local markets?

These are just some of the questions raised by the proposed spinoff mechanism. Before trying to answer them, I focused on developing simple models to structure what should be observed if indeed spinoffs were key to industrial clustering (Klepper 2005, 2007, 2010; Buenstorf and Klepper 2009, 2010). The models assume that firms entering a new industry differ at the time of entry in terms of their "competence," which conditions their productivity. The most competent entrants comprise successful firms in related industries that diversify into the new industry and spinoffs of leading incumbents, who have the most knowledge to draw on to organize their operations. ${ }^{3}$ All else equal, more competent firms produce a larger level of output,

\footnotetext{
$\overline{3}$ Not all successful firms that diversify from a related industry or that are spinoffs of leading incumbents will themselves be high-competence entrants; such a background is a necessary but not sufficient condition to be a high-competence firm.
} 
including at the time of entry. They also earn larger profits and thus are less likely to exit due to adverse random shocks, enabling them on average to survive longer. More competent firms also spawn more and better spinoffs.

Industries differ in the value of experience in related industries and within incumbent firms. Ones where experience in related industries is of less value have less successful entrants diversifying from related industries, which limits the number of geographic areas with successful firms. But if experience within leading incumbent firms is an important source of competence, the few regions with successful early firms are prime candidates for a build-up of successful spinoffs, thereby fueling clustering.

Based on these ideas, the following patterns are expected in industries subject to clustering:

(1) Clusters begin with a successful diversifier.

(2) Clusters experience a high rate of spinoffs; hence the percentage of entrants that are spinoffs is greater in clusters than elsewhere.

(3) Clusters are home to the most fertile spawners of spinoffs.

(4) The leading firms in clusters are predominantly spinoffs of other leading firms in the clusters.

(5) Spinoffs in clusters are more competent on average than spinoffs elsewhere and other kinds of new firms, denoted as startups, in all regions. This should be reflected in a higher percentage of spinoff entrants entering at large sizes and surviving longer than spinoffs elsewhere and startups in all regions.

None of these predictions depends on Marshallian agglomeration economies. Such economies are not, however, incompatible with the spinoff mechanism. If spinoffs spur the growth of clusters, agglomeration economies would reinforce the growth by benefiting all of the firms located in a cluster. So if agglomeration economies are influential, not only spinoffs but also startups in the clusters will survive longer than their counterparts elsewhere.

The five predictions were used to guide the analysis of the U.S. automobile, tire, and semiconductor industries. The analysis of the cotton garment industry focused on how the industry developed after the success of Desh Garments. Policies were implemented to allow firms to import fabric without paying duties and to help finance the purchase of inputs. The main question addressed by Mostafa and Klepper (2010) is whether these policies alone were sufficient to catalyze the growth of the industry or whether key to the growth of the industry were mechanisms to diffuse the tacit knowledge that Daewoo had imparted to Desh Garments about assembly line production.

It was initially believed that spinoffs might also have been key to the diffusion of this tacit knowledge and the growth of the industry after the success of Desh Garments. But Bangladesh's capital markets were primitive, and few of the initial workers at Desh had access to the funds required to start their own firms. However, the workers were sought after by entrants to help set up and oversee their production using assembly line methods. It was conjectured that Bangladesh's cotton garment industry initially grew as these workers left Desh Garments to help set up production at new entrants, causing the number of firms capable of competing internationally to rise.

A simple model of this hiring process was developed to structure what should be observed if the growth of the Bangladesh cotton garment industry was initially fueled by the migration of Desh Garments workers to new entrants (Mostafa and Klepper 2010). A market was assumed to arise for the Desh Garments workers, which determined the price of their services. By hiring a Desh Garments worker to set up and supervise its production, a firm could improve its productivity and thus lower its unit cost of production. The larger the firm, the greater the profits from lowering its unit cost. Similar to the spinoff model, firms differed in their innate productivity based on the background of their founders. Those founded by individuals with experience as entrepreneurs in other industries and with greater education were more productive and thus produced a larger level of output. Consequently, firms with the greatest innate productivity were expected to hire Desh Garments workers to set up and supervise their production, which would increase their productivity and exports. These firms were concentrated in Dhaka, so that is where the industry agglomerated.

\section{Tracing the origins of entrants}

The key to testing all of these predictions is tracing the backgrounds of entrants and also their performance. The greatest challenge is identifying the backgrounds of new firms, which requires working 
out who founded them and their prior work history. The sources available to trace the backgrounds of entrants differed across the four industries, which necessitated using different strategies to compile the data. As a result, the same tests of the predictions could not be performed for each industry.

The industry that could be analyzed most comprehensively was automobiles. A great deal has been written about the industry, in part due to the interest of hobbyists in vintage automobiles. To cater to their needs and the interests of others, a three-volume compendium called the Standard Catalog of American Cars was assembled to provide information on every company that was even rumored to have produced an automobile in the USA. The main volume (Kimes and Clark 1996) was an invaluable resource to trace the backgrounds of the U.S. automobile producers listed in Smith (1968).

Between Smith (1968), which also identified which producers diversified into automobiles from other industries, the Standard Catalog, and other scattered sources, the backgrounds of all 725 automobile producers listed in Smith (1968) from 1895 to 1966 were traced. Based on rules detailed in Klepper (2007), firms were divided into four categories: pre-existing firms that diversified into autos, new firms founded by heads of pre-existing firms, spinoffs and their "parents," and all other startups. Bailey (1971) was used to identify the annual leading producers of automobiles. Thomas' Register of American Manufacturers, which beginning in 1905 annually listed the producers of many manufactured products, including automobiles, was used to determine the initial capitalization of automobile producers in Smith (1968) that were also listed in Thomas' Register (Klepper 2010).

Thomas' Register was also used to compile a list of 607 producers of pneumatic automobile tire producers in the USA from 1905 to 1981, including their year of entry, year of exit, base location, and initial capitalization. For the earliest entrants in Thomas' Register, another directory was used to backdate their entry year as far back as 1901 (Klepper 2002). Various sources, including listings of rubber and tire machinery producers in Thomas' Register, were used to determine which tire entrants diversified from other industries. Over $85 \%$ of the entrants were not diversifiers, and no resource comparable to the Standard Catalog existed to trace the backgrounds of new firms.
To make it tractable to trace the backgrounds of new firms, only the 126 firms that entered in the state of Ohio through 1930 were considered. No significant entry into the industry occurred after 1930, so little was lost by focusing only on entrants through 1930. Attention was restricted to the Ohio entrants because the industry clustered there and more resources were available to trace the entrants in Ohio than elsewhere. Buenstorf and Klepper $(2009,2010)$ used a diverse set of sources, including trade journals, county histories, incorporation records, and city directories listing people and their jobs to identify the backgrounds of 117 of the 126 Ohio entrants. Based on rules detailed in Buenstorf and Klepper (2010), they were divided into three groups: diversifiers, spinoffs and their parents, and (other) startups. ${ }^{4}$ The county in Ohio (or elsewhere for the small number of entrants that came from outside Ohio) from which each of the 117 entrants originated was determined. For spinoffs and startups, this was defined as the county where their founders previously worked; for diversifiers, it was the county where they previously produced. No comprehensive data were available on the periodic market shares of the leaders except for the very top firms.

The two main sources available to trace the backgrounds and performance of semiconductor producers dictated almost the opposite strategy than that used for the tire industry. One source compiled by ICE provided annual data from 1974 to 2002 on the sales of all U.S. semiconductor companies whose sales exceeded a minimum value. ${ }^{5}$ These were the most prominent firms in the industry. The other source was the Silicon Valley genealogy noted earlier, which was used to determine the background and year of entry of all ICE firms located in Silicon Valley that had entered the industry by 1986 . The other entrants on the ICE list and their backgrounds were traced through Web searches and other sources. All told, 99 firms on the ICE lists had entered by 1986, and the backgrounds of 92 of them could be traced. Based on rules detailed in Klepper (2009), they were divided into diversifiers, spinoffs and their parents, and (other) startups.

\footnotetext{
${ }^{4}$ Few new firms were founded by heads of other firms, as in automobiles, so this category was not employed.

5 These data were graciously provided to me by Rosemarie Ziedonis.
} 
Identifying and tracing the backgrounds of firms in Bangladesh that produced cotton garments was a singular challenge. After much prodding, BGMEA provided annual directories of producers beginning in 1990 and a listing of entrants prior to 1990, including their year of entry. It also provided annual export data beginning in 1995 for the firms located in Dhaka. Extensive on-site field work was required to trace the backgrounds of the firms, which included whether they were diversifiers and whether they were headed by a college graduate. This field work uncovered an annual meeting of many of the original 126 workers at Desh Garments who had been trained by Daewoo. These workers provided their work histories and the work histories of most of the other 126 workers that did not attend the meeting, some of whom were deceased. Their work histories were used to identify all of the early entrants that hired a Desh Garments worker to set up and supervise their production.

\section{Empirical patterns}

First the three U.S. industries and their clusters are considered. Each cluster was expected to have at least one successful early entrant that was a diversifier. As already noted, in autos that firm was Olds Motor Works and in tires it was B.F. Goodrich. Both clusters also had other successful firms early on, in part due to the influence of Olds and Goodrich. In autos, Olds' subcontracting influenced the development nearby of Cadillac, Ford, and Buick. In tires, Goodrich influenced the development in Akron of Diamond Rubber, Kelly-Springfield, Goodyear Tire \& Rubber, and Firestone Tire \& Rubber, all of which were successful early firms (Buenstorf and Klepper 2009). Diamond was an 1894 spinoff of Goodrich that was later acquired by Goodrich. Kelly-Springfield held a patent on a carriage tire that it had manufactured by Goodrich, and when it decided to produce automobile tires in 1899 it entered in Akron. Firestone was organized in Akron in 1900, and its first tires were manufactured by Goodrich, which later supplied prepared rubber and fabric for Firestone's own tire manufacturing operation. Goodyear was founded in 1898 by the son of one of the local financiers of Goodrich who had his own rubber company.

The early successful semiconductor entrant in Silicon Valley was Fairchild Semiconductor. It was not a diversifier but a spinoff, which in part reflects the unusual circumstances surrounding the start of the industry and its flawed parent (Lécuyer 2006). The transistor was invented at Bell Labs, AT\&T's research arm. Under antitrust pressure, AT\&T agreed to license its transistor patents and produce transistors only for itself and the government, which opened up the commercial market for other firms. One of these was founded by William Shockley, a leading researcher at Bell Labs who shared the Nobel Prize for the transistor. He founded his firm in Silicon Valley where he was reared and his mother was still living. His original goal was to produce silicon transistors based on recent advances at Bell Labs, but he was a dysfunctional manager and soon abandoned his plans to concentrate on producing a complicated device of his own invention. This led eight of his employees to leave and found Fairchild Semiconductor to pursue Shockley's original vision, making Fairchild Semiconductor a sort of alter ego of AT\&T. Fairchild Semiconductor was immediately successful, and by 1966 it was the number two producer in the industry.

Thus, each of the clusters was characterized by a very successful early entrant, which was expected to spur the formation of spinoffs and thus a higher percentage of spinoffs entrants in the clusters than elsewhere. As reflected in Table 1, in each industry the percentage of entrants that were spinoffs was markedly higher in the clusters than elsewhere. In autos, nearly half the 110 entrants in the Detroit area were spinoffs versus $15 \%$ of the 603 entrants elsewhere. In tires, over half of the 36 entrants originating in Summit County were spinoffs versus $28 \%$ of the 67 entrants originating elsewhere in Ohio. In semiconductors, a remarkable $93 \%$ of the 59 entrants in Silicon Valley were spinoffs versus 39\% of the 33 entrants elsewhere.

Not surprisingly given these figures, the most prolific spawners of spinoffs were mainly the leading firms in the clusters, as predicted. In autos, the four early successful Detroit entrants, Olds, Buick/GM, Cadillac, and Ford, were the top spawners of spinoffs. $^{6}$ They generated 22 spinoffs and another 19 spinoffs descended from them. Collectively, their descendants accounted for $62 \%$ of the spinoffs that

\footnotetext{
${ }^{6}$ One other firm in its different incarnations (it was reorganized at one point) was tied with Cadillac and Ford for third place behind Olds and Buick/GM in total number of spinoffs.
} 
Table 1 Percentage of spinoff entrants in the clusters and elsewhere

\begin{tabular}{llll}
\hline & Auto industry & $\begin{array}{l}\text { Tire } \\
\text { industry }\end{array}$ & $\begin{array}{l}\text { Semiconductor } \\
\text { industry }\end{array}$ \\
\hline Cluster & $47 \%(52 / 110)$ & $58 \%(21 / 36)$ & $93 \%(55 / 59)$ \\
Elsewhere & $15 \%(88 / 603)$ & $28 \%(19 / 67)$ & $39 \%(13 / 33)$ \\
\hline
\end{tabular}

entered in the Detroit area through 1924. In tires, the top four spawners of spinoffs in Ohio included the top three firms in Akron, Goodrich, Firestone, and Goodyear. They had 13 spinoffs, $^{7}$ and another nine were indirect descendants founded by their exemployees (who first moved to other tire producers). Collectively, their direct and indirect descendants accounted for $52 \%$ of the spinoffs that entered within 100 miles of Akron. In semiconductors, Fairchild Semiconductor alone spawned 14 spinoffs, more than any firm in the industry, and another 17 spinoffs descended from them. Furthermore, 14 other spinoffs were founded by ex-employees of Fairchild Semiconductor or were descended from these spinoffs. Collectively, Fairchild Semiconductor's direct and indirect descendants accounted for $82 \%$ of the spinoffs that entered in Silicon Valley.

As predicted, spinoffs of the leading firms in the clusters were a force in all three industries, especially in autos and semiconductors. The early auto and semiconductor leaders were predominantly diversifiers, but most of them were displaced by spinoffs of leading firms in the clusters (Klepper 2010). Among the 16 automobile firms that entered after 1902 and produced one of the top ten best-selling makes of automobiles in one or more years through 1924, 12 were spinoffs descended from Olds, Buick/GM, Cadillac, and Ford, and all but one was located in the Detroit area. ${ }^{8}$ Among the 11 semiconductor firms

\footnotetext{
$\overline{7}$ Goodrich acquired Diamond, which had one spinoff that is included with Goodrich's other four spinoffs.

8 Table 6 in Klepper (2009) lists the automobile firms that periodically produced leading makes and their year of entry. Among the 18 firms in Table 6 that entered after 1902, all but Paige-Detroit and Dort made it into the top ten producers in one or more years. Figure 4 in Klepper (2007) provides a genealogy of the spinoffs descended from Olds, Cadillac, Ford, and Buick/GM which reflects their 12 descendants that produced a top ten best-selling make of automobile in one or more years.
}

that entered after 1960 and made it into the ranks of the top ICE producers in one or more years through 2002, seven were spinoffs located in Silicon Valley that were directly or indirectly descended from Fairchild Semiconductor. ${ }^{9}$ In tires, comprehensive market share data for all but the top firms are lacking. Instead, the longevity of firms is used as a proxy for their performance. There was little turnover among the very top Ohio firms, which generally were very long-lived. However, spinoffs of the leading firms were prominent among the other long-lived Ohio entrants. Among the 16 Ohio firms other than the early Akron leaders that survived 20 or more years, seven were direct or indirect descendants of Goodrich, Goodyear, and Firestone, and six of the seven were located in Summit County. ${ }^{10}$

It was expected that clusters would be distinguished by having a larger percentage of spinoffs entering at large sizes than spinoffs elsewhere and startups in all regions. Data from Thomas' Register on the capitalization of firms were used to measure the size of auto and tire firms when they entered. Each firm's capitalization is reported in one of 11 intervals. Tables 2 and 3 report the percentage of spinoffs and startups in the clusters and elsewhere with initial capitalization above $\$ 1$ million (the top category) and above $\$ 300,000$ (the top three categories). ${ }^{11}$ Consistent with expectations, spinoffs in the clusters stand out. In autos, few firms entered with capital of over $\$ 1$ million, but the percentage was higher for spinoffs in Detroit than for spinoffs elsewhere and startups in Detroit and elsewhere. The differences are more pronounced for initial capital above $\$ 300,000-17.3 \%$ of the Detroit spinoffs

\footnotetext{
9 The 11 firms are listed under the category of later entrants in Table 1 in Klepper (2009). Among the seven located in Silicon Valley, Signetics, National, Intel, AMD, and LSI Logic were spinoffs of Fairchild Semiconductor and AMI and VLSI Technology were founded by ex-employees of Fairchild Semiconductor (who had moved to other firms before founding their spinoffs).

${ }^{10}$ In ascending order of longevity, the 16 firms are Bucyrus, Falls, Rubber Products, Victor, Star, Swinehart, Monarch, Pharis, Seiberling, Amazon, Dayton, Denman-Myers, General, Giant/Cooper, Mohawk, and Mansfield. Falls, Swinehart, Seiberling, and General were spinoffs of Goodrich, Firestone, and Goodyear, and Amazon, Denman-Myers, and Mohawk were founded by ex-employees of these firms.

${ }^{11}$ Table 2 is compiled from the data reported in Table 7 in Klepper (2010). Table 3 is based on data reported in Buenstorf and Klepper (2009) in Table 8, broken down by region.
} 
Table 2 Percentage of automobile spinoffs and startups with the largest initial capital

\begin{tabular}{lllll}
\hline Initial capital & Detroit spinoffs $(\%)$ & Other spinoffs $(\%)$ & Detroit startups $(\%)$ & Other startups $(\%)$ \\
\hline$>\$ 1$ million & 7.7 & 1.1 & 0.0 & 1.3 \\
$>\$ 300,000$ & 17.3 & 4.4 & 5.4 & 3.6 \\
\hline
\end{tabular}

Table 3 Percentage of tire spinoffs and startups with the largest initial capital

\begin{tabular}{lcccr}
\hline Initial capital $(\%)$ & Summit spinoffs $(\%)$ & Other spinoffs $(\%)$ & Summit startups $(\%)$ & Other startups $(\%)$ \\
\hline$>\$ 1$ million & 7.1 & 0.0 & 7.1 & 0.0 \\
$>\$ 300,000$ & 42.8 & 10.0 & 14.2 & 11.8 \\
\hline
\end{tabular}

entered at this size versus 3.6-5.4\% of firms in the other three groups. In tires, only two firms, one Summit County spinoff and startup, entered with initial capital above $\$ 1$ million. For initial capital above $\$ 300,000$, the spinoffs in Summit County stand out $-42.8 \%$ entered at this size versus $10.0-14.2 \%$ for the other three groups of firms.

Klepper $(2007,2010)$ and Buenstorf and Klepper (2009) analyzed the longevity of auto and tire producers. Without controlling for firm backgrounds and time of entry, firms in Detroit and Akron had lower annual hazards of exit than firms elsewhere. In autos, the lower hazard of the Detroit entrants was confined to spinoffs located there, and in particular to spinoffs of the leading firms that entered at larger sizes (Klepper 2010). Buenstorf and Klepper (2009) found that not only did the early tire entrants in Summit County have lower hazards, but so did subsequent entrants there. Similar to autos, the lower hazards of the later entrants in Summit County were confined to spinoffs located there, and in particular to the ones that descended directly or indirectly from the top three Akron firms and entered at larger sizes. The performance of startups in both the Detroit area and Summit County was not distinctive relative to startups elsewhere, which casts doubt on whether firms in the clusters benefitted from agglomeration economies. Semiconductor firms in Silicon Valley were also exemplary performers. But all of them were spinoffs, so it was not possible to separate the effects of background from regional effects related to agglomeration economies.

The analysis that was conducted for the cotton garment industry in Bangladesh focused on which firms hired Desh Garments workers to set up their production and the effect of hiring the Desh Garments workers on the firm's exports (Mostafa and Klepper 2010). Among the 664 entrants through 1988, 59 hired Desh Garments workers to set up their production. Consistent with the predictions, the probability of hiring a Desh Garments worker to set up production was over threefold greater both for diversifiers and college-educated founders. After controlling for the effects of these backgrounds on the level of a firm's exports, hiring a Desh worker more than doubled a firm's exports as of 1995. The estimates were robust to attempts to use instruments and other measures of firm performance to control for the effects of unobservable aspects of firms' backgrounds on their performance.

Mostafa and Klepper (2010) also analyzed a secondary diffusion process in which workers in another successful firm that itself hired Desh Garments workers to set up its production were hired by entrants to set up and supervise their production. As predicted, the types of firms that hired them were similar to the types that hired the Desh Garments workers, and hiring them improved an entrant's performance, but both effects were more muted than hiring the Desh Garments workers. This would be consistent with these workers also possessing valuable tacit knowledge about production, but less thorough and hence less valuable knowledge than the original workers trained so extensively by Daewoo.

\section{Questions and policy}

The four clusters share a number of features. All began with a single seed. In semiconductors and 
cotton garments, the seed was the main catalyst for the growth of their clusters, whereas in autos and tires other successful firms related to the seed also catalyzed the growth of their clusters. Chance no doubt played a critical role in the seeding of each of the clusters and thus their location. Subsequently, though, the evolution of the clusters followed a similar path. The movement of employees from the initial seed(s) to new firms either founded or shaped by the employees propagated the original seed(s). The new firms located close to where their founders were previously working and living, which in the case of spinoffs led to a buildup of firms around successful early producers. Spinoffs with the right pedigree or, in the case of the Bangladesh cotton garment industry, new firms with the right heritage, enabled the clusters to capture an increasing share of their industry's activity, fueling growth of the clusters and their surrounding regions.

Spinoffs are by no means prominent in all industries, which would help explain why some industries do not exhibit much clustering. A quintessential example is the TV receiver industry in the USA, whose geographical evolution is considered in Klepper (2005). About one-third of the entrants into the TV receiver industry were diversifiers from the radio industry. Radio firms were concentrated around three cities in the USA: New York, Los Angeles, and Chicago. Entrants into the TV receiver industry were even more concentrated in these three cities $-73 \%$ of the 177 entrants into the TV receiver industry were in these cities. In contrast, in autos, tires, and semiconductors, entrants were far more dispersed, with only about $20 \%$ locating in the clusters. So by rights, the TV receiver industry should have evolved to have been heavily concentrated geographically. However, over time the industry became less concentrated geographically, with first New York and then Los Angeles losing all of its producers. The reason for this development was that all of the leading TV receiver producers were diversifiers from the radio industry. No spinoffs made it into the ranks of the leaders, and without spinoffs the industry de-agglomerated over time.

Numerous questions are raised by the proposed spinoff account of clustering. Most fundamentally, why do spinoffs occur-why do employees leave successful firms to found their own firms in the same industry? What do spinoffs inherit-what do employees learn as a byproduct of their employment that is useful in setting up their own firm? Why are not all top-performing firms equally fertile sources of spinoffs? Why, for example, did Fairchild Semiconductor have so many more spinoffs than Texas Instruments even though both followed extraordinarily similar technological paths during their formative years (Klepper 2010)? Why do spinoffs locate close to their parents? How do spinoffs spur the growth of clusters-how do they result in added activity in a cluster rather than just divert activity from their parent? Even after controlling for various firm and industry determinants of spinoffs, Klepper (2010) found that the rate at which automobile and semiconductor firms spawned spinoffs was higher in the clusters. Why-is this indicative of some sort of agglomeration economy? Last, why aren't spinoffs prominent in all industries?

I have broached a number of these questions in recent joint papers (Carias and Klepper 2010; Klepper and Thompson 2010; Cheyre et al. 2011). Rather than dwell on these questions, I close by discussing broad policy implications of the findings. Four cases, albeit extreme ones, hardly provide the basis for making policy, but it is worthwhile reflecting on the policy levers that might be tapped to promote the kind of growth that the four clusters experienced.

The findings suggest that incumbent firms can play a central role in training the next generation of entrepreneurs in an industry. However, incumbents are rarely involved in sponsoring their spinoffs, so they have no incentive to play this training role. Worse, spinoffs may try to hire employees from their parents and may also compete with their parents for sales. So it is natural for parents to want to suppress spinoffs in any way possible. Intel is a case in point. The founders of Intel, Robert Noyce and Gordon Moore, were also founders of Fairchild Semiconductor, which was weakened by a steady defection of employees to found their own firms. They vowed not to experience that at Intel and according to some accounts took draconian legal measures to intimidate employees who sought to found their own firms (Jackson 1997). One role that policy can play is to prevent incumbents from such intimidation and, more generally, to facilitate the formation of spinoffs.

The findings suggest that the mobility of workers who possess valuable tacit knowledge plays a key role in the creation of new firms that propel industries 
forward. Certainly this mobility can also weaken incumbents, so it is a double-edged sword. But the overall mobility of workers seems to have been key to the tremendous growth experienced in each of the clusters. In the USA, high-level employees commonly sign covenants not to compete with their employers for some specific length of time after leaving their employ. With the exception of a few states in the USA, most prominently California, most states allow such covenants to be enforced (Gilson 1999), and their enforcement appears to reduce mobility (Marx et al. 2009). The fact that Silicon Valley is in California is suggestive that maybe the benefits of not allowing such covenants to be enforced outweigh any harmful effects on incumbents.

All four of the clusters began with a seed that catalyzed their growth. This quite naturally raises the question as to whether government policy could be productively used to plant such seeds deliberately. That is a far-reaching question that cannot be easily answered. It is worth pointing out, however, that at least in the case of the semiconductor industry, the military was the largest customer early on for advanced semiconductor devices, which proved to be instrumental in the success of Fairchild Semiconductor (Lécuyer 2000), the seed for the Silicon Valley semiconductor cluster. While the military had its own objectives, it is instructive that the semiconductor industry and the Silicon Valley cluster certainly owes its success in part to a government entity. Taiwan's success in the semiconductor industry is perhaps even more instructive about the planting of seeds by government agencies. The first semiconductor company entered in 1980 and by the late 1990s Taiwan was the fourth largest semiconductor producer in the world behind the USA, Japan, and Korea. The impetus for its entire industry was a research institute sponsored by the government in the 1970s, and the government was proactive in getting private companies to emerge from the institute at the start of the industry in the 1980s (Mathews and Cho 2000).

One of the dividends of exploring the mechanisms underlying clustering in the four industries is that it focuses attention on novel policies. It also highlights numerous questions regarding spinoffs that can be productively addressed. Hopefully the nano-economic exercise of dissecting the evolution of the four clusters will encourage others to pursue a similar tact and begin to get to the hub of how public policy can promote the kind of growth that the four clusters exemplify.

Acknowledgments I thank Serguey Braguinsky, Guido Buenstorf, John Miller, Romel Mostafa, and Francisco Veloso for helpful comments.

Open Access This article is distributed under the terms of the Creative Commons Attribution Noncommercial License which permits any noncommercial use, distribution, and reproduction in any medium, provided the original author(s) and source are credited.

\section{References}

Audretsch, D. B., \& Feldman, M. P. (2004). Knowledge spillovers and the geography of innovation. In J. V. Henderson \& J. F. Thisse (Eds.), Handbook of urban and regional economics (Vol. 4). Amsterdam: North Holland.

Bailey, L. S. (1971). The American car since 1775. New York: Automobile Quarterly, Inc.

Buenstorf, G., \& Klepper, S. (2009). Heritage and agglomeration: The Akron tire cluster revisited. Economic Journal, 119(537), 705-733.

Buenstorf, G., \& Klepper, S. (2010). Why does entry cluster geographically? Evidence from the U.S. tire industry. Journal of Urban Economics, 68(2), 103-114.

Carias, C., \& Klepper, S. (2010). Entrepreneurship, the initial labor force, and the location of new firms. Mimeo.

Cheyre, C., Klepper, S., \& Veloso, F. (2011). Spinoffs and the mobility of US merchant semiconductor inventors. Mimeo.

Doolittle, J. R. (1916). The romance of the automobile industry. New York: Klebold Press.

Ellison, G., Glaeser, E. L., \& Kerr, W. R. (2010). What causes industry agglomeration? Evidence from coagglomeration patterns. American Economic Review, 100(3), 1195-1213.

Federal Trade Commission (1939). Report on the motor vehicle industry. Washington, DC: U.S. Government Printing Office.

Gilson, R. J. (1999). The legal infrastructure of high technology industrial districts: Silicon Valley, Route 128, and covenants not to compete. New York University Law Review, 74(3), 575-629.

Jackson, T. (1997). Inside Intel. New York: Plume.

Jaffe, A. B., Trajtenberg, M., \& Henderson, R. (1993). Geographic localization of knowledge spillovers as evidenced by patent citations. Quarterly Journal of Economics, 108(3), 577-598.

Jaffe, A. B., Trajtenberg, M., \& Henderson, R. (2005). Patent citations and the geography of knowledge spillovers: A reassessment: Comment. American Economic Review, 95(1), 461-464.

Kimes, B. R., \& Clark, H. A., Jr. (1996). Standard catalog of American cars, 1890-1942 (3rd ed.). Iola, WI: Krause Publications.

Klepper, S. (2002). Firm survival and the evolution of oligopoly. RAND Journal of Economics, 33(1), 37-61. 
Klepper, S. (2005). The geography of organizational knowledge. Mimeo.

Klepper, S. (2007). Disagreements, spinoffs, and the evolution of Detroit as the capital of the US automobile industry. Management Science, 53(4), 616-631.

Klepper, S. (2009). Silicon Valley-a chip off the old Detroit bloc. In Z. Acs, D. B. Audretsch, \& R. Strom (Eds.), Entrepreneurship, growth, and public policy (pp. 79-115). Cambridge: Cambridge University Press.

Klepper, S. (2010). The origin and growth of industry clusters: The making of Silicon Valley and Detroit. Journal of Urban Economics, 67(1), 15-32.

Klepper, S., \& Thompson, P. (2010). Disagreements and intraindustry spinoffs. International Journal of Industrial Organization, 28(5), 526-538.

Krugman, P. (1991). Geography and trade. Cambridge, MA: MIT Press.

Lécuyer, C. (2000). Fairchild semiconductor and its influence. In C. M. Lee, W. F. Miller, M. G. Hancock, \& H. S. Rowen (Eds.), The Silicon Valley edge (pp. 158-183). Stanford, CA: Stanford University Press.

Lécuyer, C. (2006). Making Silicon Valley. Cambridge, MA: MIT Press.

Marshall, A. (1920). Principles of economics. London: Macmillan.

Marx, M., Strumsky, D., \& Fleming, L. (2009). Noncompetes and inventor mobility: Specialists, stars, and the Michigan experiment. Management Science, 55(6), 875-889.
Mathews, J. A., \& Cho, D. S. (2000). Tiger technology. Cambridge: Cambridge University Press.

Mostafa, R., \& Klepper, S. (2010). Industrial development through tacit knowledge seeding: Evidence from the Bangladesh garment industry. Mimeo.

Puga, D. (2010). The magnitude and causes of agglomeration economies. Journal of Regional Science, 50(1), 203-219.

Rosenthal, S. S., \& Strange, W. C. (2004). Evidence on the nature and sources of agglomeration economies. In J. V. Henderson \& J. F. Thisse (Eds.), Handbook of urban and regional economics (Vol. 4, pp. 2119-2171). Amsterdam: North Holland.

Smith, P. H. (1968). Wheels within wheels. New York: Funk and Wagnalls.

Thompson, P., \& Fox-Kean, M. (2005a). Patent citations and the geography of knowledge spillovers: A reassessment. American Economic Review, 95(1), 450-460.

Thompson, P., \& Fox-Kean, M. (2005b). Patent citations and the geography of knowledge spillovers: A reassessment: Reply. American Economic Review, 95(1), 465-466.

Tilton, J. E. (1971). International diffusion of technology: The case of semiconductors. Washington, DC: The Brookings Institution. 